\title{
DVR with Modified Y Source Inverter and MCFC
}

\author{
Jaydeep Chakravorty \\ Electrical Engineering Department \\ Indus University \\ Ahmedabad, India
}

\author{
Geena Sharma \\ Electrical Engineering Department \\ Baddi University \\ Himachal Pradesh, India
}

\begin{abstract}
Power quality is a big challenge nowadays. Various disturbances present in the power system are voltage sag, voltage swell, harmonics, transients, interruptions, voltage collapse etc. To solve the problem of power quality, various custom power devices are generally used in a power system, dynamic voltage restorer (DVR) being one of them. DVR is used for the compensation of voltage sag and swell. In this paper, a model of DVR with molten carbonate fuel cell (MCFC) and Y source inverter is proposed. The proposed model is compared with the existing ones to check its performance characteristics. MATLAB/SIMULINK was been used to check and compare the performance of the proposed with existing models.
\end{abstract}

\section{Keywords-Y source inverter; DVR; $M C F C$}

\section{INTRODUCTION}

Most conventional inverters commonly used in power systems are voltage source inverters (VSI) and current source inverters (CSI). These traditional voltage source inverters have two major drawbacks: AC output voltage is less than the DC input voltage, so it is operated only in buck mode, and two switches in the same phase leg cannot turn on simultaneously, since this will create a short-circuit in the system. To overcome these problems impedance network has proven to be more effective and efficient in power conversion between the source and the load over a wide range of electric power applications. Various impedance networks have been proposed with Zsource [1] impedance being the pioneer and prominent network. It has been used in DC-DC [2], DC-AC [3], and AC$\mathrm{AC}$ [4]. In the later stages some modified Z-source inverters were proposed like quasi-Z [5, 6], embedded-Z [7, 8], series-Z [9] etc. Authors in [12] applied Z source inverter in DVR along with molten carbonate fuel cell (MCFC). This improved the performance of the system to a great extent. In this paper, $\mathrm{Y}$ source inverter has been used in the DVR with MCFC and its performance has been compared with existing models $[10,11]$. The proposed Y-source inverter consists of a DC source, Yimpedance network and pulse width modulation (PWM). The complete model has been simulated in Matlab/Simulink. A comparison between different network topologies based on passive components count is shown in Table I.

\section{PROPOSED Y SOURCE INVERTER}

The proposed Y-source network in this study has a diode $\mathrm{D}$, two capacitors $\mathrm{C} 1$ and $\mathrm{C} 2$ and a three winding transformers (W1, W2 and W3), as shown in Figure 1.
TABLE I COMPARISON TABLE

\begin{tabular}{|c|c|c|c|}
\hline $\begin{array}{c}\text { Name of } \\
\text { Inverter }\end{array}$ & $\begin{array}{c}\text { Number of } \\
\text { Capacitors }\end{array}$ & Number of Inductors & $\begin{array}{c}\text { Number } \\
\text { of Diodes }\end{array}$ \\
\hline Z Source & 2 & 2 & 1 \\
\hline Quasi Z Source & 2 & 2 & 1 \\
\hline Г Source & 2 & 1 inductor, 2 windings & 1 \\
\hline Trans Z Source & 2 & 1 integrated, 2 windings & 1 \\
\hline Y Source & 1 & 1 integrated winding & 1 \\
\hline
\end{tabular}

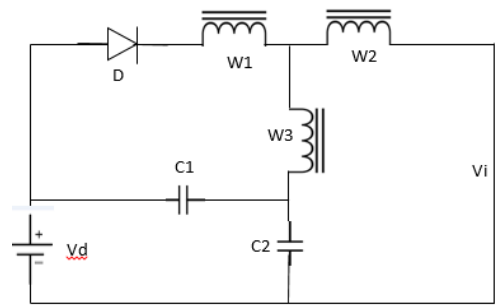

Fig. 1. Proposed Y source inverter.

The proposed Y-source network has a shoot-through and non-shoot-through operation. For shoot-through-operation the circuit is shown in Figure 2.

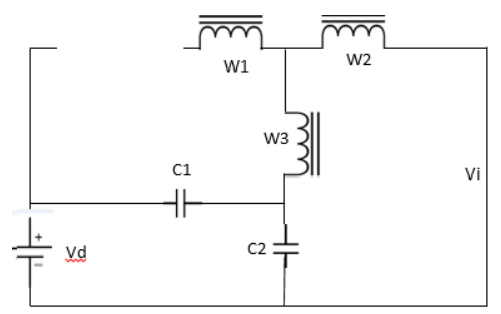

Fig. 2. Circuit for shoot-through operation.

Let $V_{W I}$ be the voltage drop across $\mathrm{W} 1$. Then from the circuit of Figure 2 we have:

$$
\begin{aligned}
& \mathrm{V}_{\mathrm{d}}+\mathrm{V}_{\mathrm{C} 1}=\mathrm{V}_{\mathrm{C} 2} \\
& \mathrm{~V}_{\mathrm{d}}+\mathrm{V}_{\mathrm{C} 1}=\frac{\mathrm{V}_{\mathrm{W} 1}}{\frac{\mathrm{N}_{1}}{\mathrm{~N}_{3}}}-\frac{\mathrm{V}_{\mathrm{W} 1}}{\frac{\mathrm{N}_{1}}{\mathrm{~N}_{2}}}=\frac{\mathrm{V}_{\mathrm{W} 1}\left(\mathrm{~N}_{3}-\mathrm{N}_{2}\right)}{\mathrm{N}_{1}}
\end{aligned}
$$

or $V_{W 1}=\frac{\left(V_{d}+V_{C 1}\right) N_{1}}{N_{3}-N_{2}}$

The circuit for non-shoot-through operation is shown in Figure 3. Let, $V_{i}$ be the DC link voltage, $d s h$ the shoot through zero state of the inverter and $M$ the modulation index. 


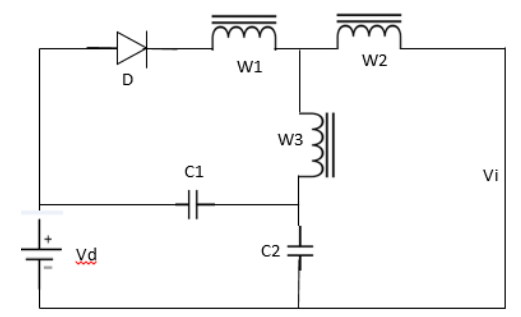

Fig. 3. Circuit for non shoot through operation.

From the circuit of Figure 3 we have:

$$
\begin{aligned}
& V_{W 1}=-\frac{\frac{N_{1}}{N_{2}}}{1+\frac{N_{1}}{N_{2}}} V_{C 1} \quad, \text { or } \\
& V_{W 1}=-\frac{N_{1}}{N_{1}+N_{2}} V_{C 1}
\end{aligned}
$$

And

$V_{d c}=V_{i}+V_{W 1}+\frac{V_{W 1}}{\frac{N_{1}}{N_{2}}} \quad$, or

$V_{d c}=V_{i}+V_{W 1}\left(\frac{N_{1}+N_{2}}{N_{1}}\right)$

Again, $V_{C 1}=\frac{\left(\frac{1+\frac{N_{1}}{N_{2}}}{\frac{N_{3}}{N_{2}}-1}\right) d s h}{1-\left(\frac{1+\frac{N_{1}}{N_{3}}}{1-\frac{N_{2}}{N_{3}}}\right) d s h}$, or

$V_{C 1}=\frac{\left(\frac{N_{1}+N_{2}}{N_{3}-N_{2}}\right) d s h}{1-\left(\frac{N_{3}+N_{1}}{N_{3}-N_{2}}\right) d s h}$

and $V_{C 2}=\frac{1-d s h}{1-\left(\frac{N_{3}+N_{1}}{N_{3}-N_{2}}\right)} V_{W 1}$

The peak value of the DC link voltage of the inverter is:

$$
V_{i}(d c p)=\frac{1}{1-\left(\frac{N_{3}+N_{1}}{N_{3}-N_{2}}\right)} V_{W 1}
$$

The peak value of AC voltage per phase:

$$
V_{i}(a c p)=\frac{M}{1-\left(\frac{N_{3}+N_{1}}{N_{3}-N_{2}}\right) d s h} \frac{V_{W 1}}{2}
$$

If the values of the capacitor $\mathrm{C}_{1}$ and $\mathrm{C}_{2}$ are selected properly then the network can give continuous current with very little ripple.

\section{CONTROL TECHNIQUe}

For the proposed model, the same fuzzy controller as in [12] has been used. The Simulink model of fuzzy controller is shown in Figure 4.

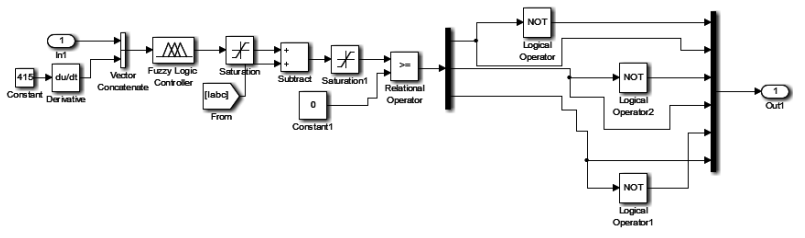

Fig. 4. Fuzzy control technique.

\section{PROPOSED MODEL}

The proposed $\mathrm{Y}$ source inverter has been applied to the DVR model with MCFC [12]. The complete Simulink model of the DVR with MCFC, ultra-capacitor and Y source inverter is shown in Figure 5.

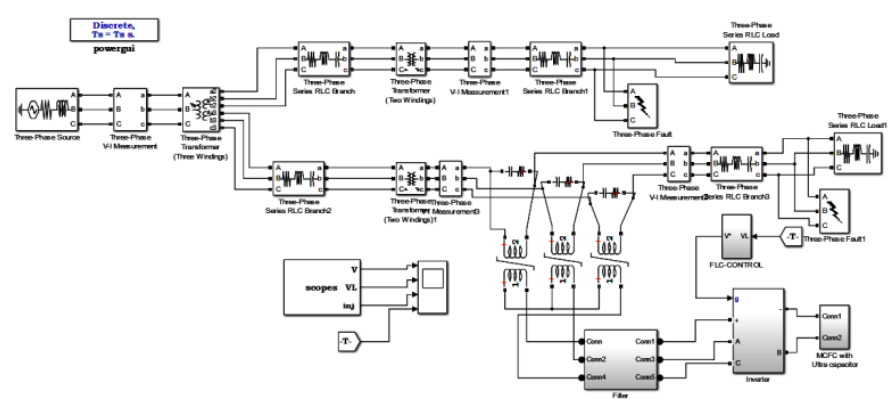

Fig. 5. Proposed DVR model with Y source inverter.

The schematic model of a MCFC is shown in Figure 6. A fuel cell converts chemical energy into electrical energy. In MCFC $\mathrm{CO}_{2}$ gas moves from the cathode to the anode through a molten electrolyte. Here molten carbonate salt acts as an electrolyte where two porous electrodes are present. The electrode layer is formed in sub layers. Between the gas and the electrode a thin porous metal plate is inserted. This acts as a diffuser, it helps in helping the gas mixture to enter into the porous electrode. When the $\mathrm{CO}_{2}$ combines with $\mathrm{O}_{2}$ in the cathode gives carbonate ions and when it combines with hydrogen in the anode side it gives $\mathrm{CO}_{2}$ and $\mathrm{H}_{2} \mathrm{O}$. So there will be a movement of electrolyte from the anode's side to the cathode side. The gas reaction at the anode side is:

$$
\mathrm{CO}+\mathrm{H}_{2} \mathrm{O} \leftrightarrow \mathrm{CO}_{2}+\mathrm{H}_{2}
$$

The electrochemical half reaction is:

$\mathrm{H}_{2}+\mathrm{CO}_{3}^{--} \leftrightarrow \mathrm{CO}_{2}+\mathrm{H}_{2} \mathrm{O}+2 \mathrm{e}$

Similarly the equation of cathode side will be

$$
\frac{1}{2} \mathrm{O}_{2}+\mathrm{CO}_{2}+2 \mathrm{e} \leftrightarrow \mathrm{CO}_{3}^{--}
$$

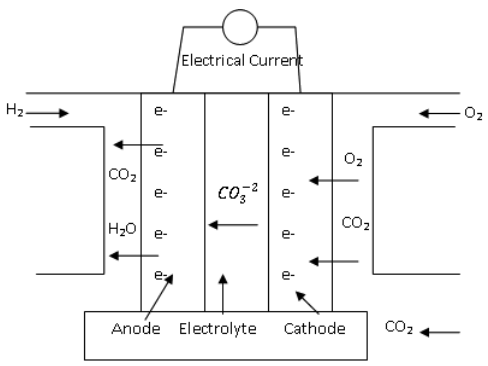

Fig. 6. MCFC

The equivalent electrical circuit of a singular cell MCFC can be seen in [13]. Authors in [12] provided the details of the operation of MCFC and the detailed Matlab/Simulink representation of MCFC and its application in DVR. In this paper the same MCFC model with DVR has been used. The new proposed $\mathrm{Y}$ source inverter in this paper has been applied to this model. The proposed model in this paper is compared 
with the model of DVR with MCFC, ultra-capacitor and Z source inverter presented in [12]. The system parameters used for testing are given in Table II.

TABLE II. SYSTEM PARAMETERS

\begin{tabular}{|c|c|c|}
\hline Parameters & $\begin{array}{c}\text { DVR with Z source } \\
\text { inverter [12] }\end{array}$ & $\begin{array}{c}\text { Proposed DVR with } \\
\text { Y source inverter }\end{array}$ \\
\hline Voltage & $120 \mathrm{~V}$ & $120 \mathrm{~V}$ \\
\hline Frequency & $50 \mathrm{~Hz}$ & $50 \mathrm{~Hz}$ \\
\hline Transformer & $1 \mathrm{KVA}$ & $1 \mathrm{KVA}$ \\
\hline Load & $\mathrm{R} \mathrm{L}$ & $\mathrm{R} \mathrm{L}$ \\
\hline DC source & MCFC & MCFC \\
\hline Type of inverter & $\mathrm{Z}$ sourced & Y sourced \\
\hline Filter & $\mathrm{R}=0.4 \Omega, \mathrm{L}=3 \mathrm{mH}$, & $\mathrm{R}=1.3 \Omega, \mathrm{L}=38 \mathrm{mH}$, \\
$\mathrm{C}=25 \mu \mathrm{F}$ & $\mathrm{C}=195 \mu \mathrm{F}$ \\
\hline
\end{tabular}

\section{SIMULATION RESULTS}

The profile of supply voltage, load injected voltage and load voltage of the new proposed DVR with Y source inverter and MCFC is shown in Figure 7. The profile of the new proposed DVR for single phase sag and swell is shown in Figure 8 . The profile of the new proposed DVR for three phase sag and swell is shown in Figure 9. The comparison of the proposed DVR with Y source inverter and the DVR model of [12] is given in Table III. The THD analysis of the model in [12] is shown in Figure 10 and the THD analysis of the proposed model is shown in Figure. 11.

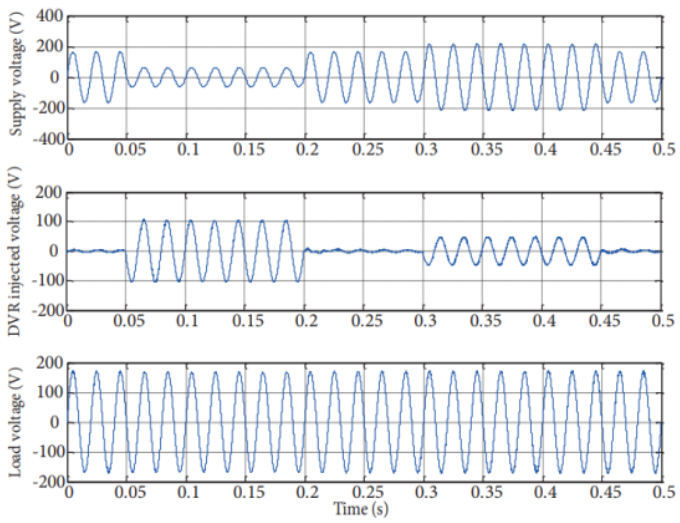

Fig. 7. Profile of proposed DVR with Y source inverter.
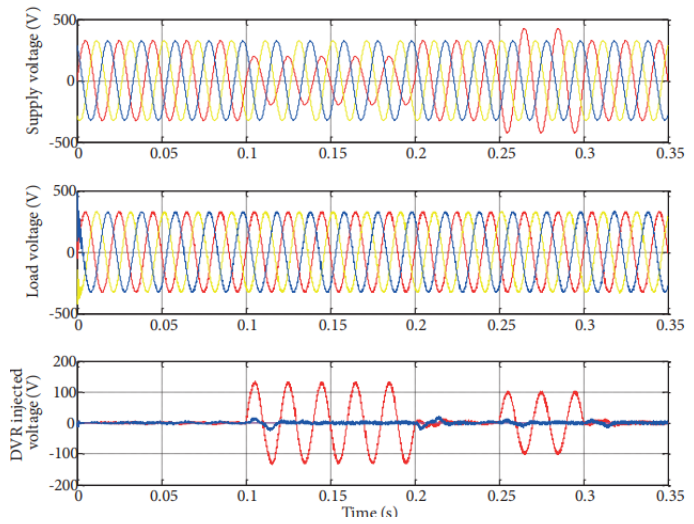

Fig. 8. Single phase sag and swell profile of proposed DVR.
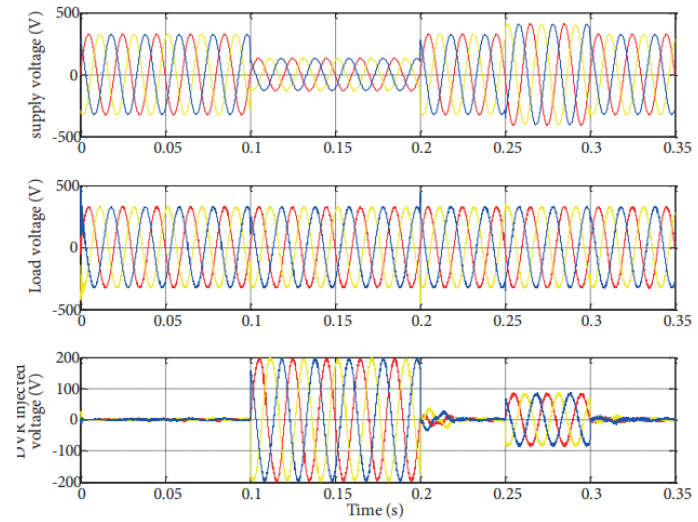

Fig. 9. Three phase sag and swell profile of proposed DVR.

TABLE III. COMPARISON TABLE

\begin{tabular}{|c|c|c|}
\hline \multirow{2}{*}{$\begin{array}{c}\text { Percentage of } \\
\text { voltage sag }\end{array}$} & $\begin{array}{c}\text { DVR with Z source } \\
\text { inverter [12] }\end{array}$ & $\begin{array}{c}\text { Proposed DVR with } \\
\text { Y source inverter }\end{array}$ \\
\cline { 2 - 3 } & $\begin{array}{c}\text { Percentage of THD in } \\
\text { DVR injected voltage }\end{array}$ & $\begin{array}{c}\text { Percentage of THD in } \\
\text { DVR injected voltage }\end{array}$ \\
\hline 10 & 1.5 & 0.58 \\
\hline 30 & 2.4 & 0.63 \\
\hline 50 & 2.3 & 0.72 \\
\hline 70 & 2.2 & 0.79 \\
\hline 90 & 2.1 & 0.67 \\
\hline
\end{tabular}

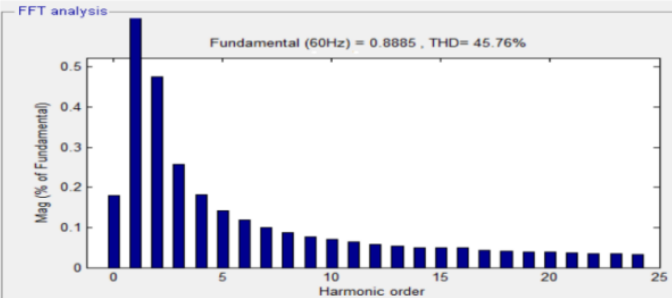

Fig. 10. THD analysis of the model of [12]

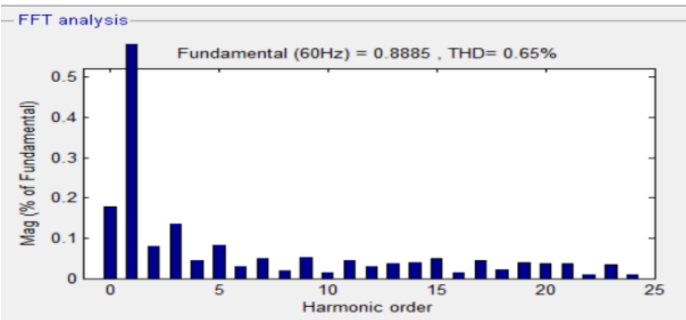

Fig. 11. THD Analysis of proposed model with Y source inverter

\section{CONCLUSION}

The proposed model has been simulated in Matlab/Simulink and gave good convergence with ode23s. But the speed of simulation was observed to be very slow. The proposed inverter has more circuit elements which makes it more complicated. It has been observed that in $\mathrm{Y}$-source inverter voltage gain is very high when operated at higher modulation index. The proposed DVR is capable of injecting appropriate voltages even when the system is subjected to deep voltage sags, without the need to have an energy source of higher rating. The proposed DVR performs robustly with reduced THD in the load voltage while keeping the stored 
energy requirement low. From the above analysis it is clear that MCFC based DVR with fuzzy control is the most efficient device for the improvement of power quality in the power system. The THD level of the proposed model was found to be low compared with the model proposed in [12]. The proposed model is thus much better in comparison with the model in [12].

\section{REFERENCES}

[1] F. Z. Peng, "Z-source inverter", IEEE Transactions on Industry Applications, Vol. 2, No. 39, pp. 504-510, 2003

[2] H. Cha, F. Z. Peng, D. W. Yoo, "Distributed impedance network (Z network) dc-dc converter", IEEE Transactions on Power Electronics, Vol. 11, No. 25, pp. 2722-2733, 2010

[3] Y. Tang, S. Xie, C. Zhang, "Z-source ac-ac converters solving commutation problem", IEEE Transaction on Power Electronics, Vol. 2, No. 22, pp. 2146-2154, 2007

[4] X. P. Fang, Z. M. Qian, F. Z. Peng, "Single-phase Z-source PWM ac-ac converters", IEEE Power Electronics Letters, Vol. 4, No. 3, pp. 121-124, 2005

[5] J. Anderson, F. Z. Peng, "Four quasi-Z-source inverters", 2008 IEEE Power Electronics Specialists Conference, Rhodes, Greece, August 8, 2008

[6] P. C. Loh, F. Gao, F. Blaabjerg, A. L. Goh, "Buck-Boost Impedance Networks", 2007 European Conference on Power Electronics and Applications, Aalborg, Denmark, January 4, 2008

[7] J. Anderson, F. Z. Peng, "A class of quasi-Z-source inverters", 2008 IEEE Industry Applications Society Annual Meeting, Edmonton, Canada, October 5-9,2008

[8] P. C. Loh, F. Gao, F. Blaabjerg, "Embedded EZ-source inverters", IEEE Transactions on Industry Applications, Vol. 46, No. 1, pp. 256-267, 2010

[9] Y. Tang, S. Xie, C. Zhang, "An improved Z-source inverter", IEEE Transactions on Power Electronics, Vol. 26, No. 12, pp. 3865-3868, 2011

[10] C. Bharatiraja, S. Jeevananthan, R. Latha, "FPGA based practical implementation of NPC-MLI with SVPWM for an autonomous operation PV system with capacitor balancing", International Journal of Electrical Power and Energy Systems, Vol. 61, No. 1, pp. 489-509, 2014

[11] G. Prakash, C. Subramani, C. Bharatiraja, M. Shabin, "A low cost single phase grid connected reduced switch PV inverter based on time frame switching scheme", International Journal of Electrical Power \& Energy Systems, Vol. 77, pp. 100-111, 2016

[12] J. Chakravorty, G. Sharma, V. Bhatia, "Analysis of a DVR with Molten Carbonate Fuel Cell and Fuzzy Logic Control", Engineering, Technology \& Applied Science Research, Vol. 8, No. 2, pp. 2673-2679, 2018

[13] J. Milewski, A. Miller, "Influences of the type and thickness of electrolyte on solid oxide fuel cell hybrid system performance", Journal of Fuel Cell Science and Technology, Vol. 3, No. 4, pp. 396-402, 2006 